\title{
O APROVEITAMENTO DO MAR AO LONGO DO TEMPO. A DOCUMENTACIÓN DO XACEMENTO ROMANO DE CANEXOL (ILLA DE ONS, BUEU) ${ }^{1}$
}

\author{
THE SEA EXPLOITATION OVER TIME. \\ DOCUMENTATIO OH THE ROMAN SITE OF \\ CANEXOL (ILLA DE ONS, BUEU)
}

\author{
PAULA BALLESTEROS ARIAS \\ LaPa - Laboratorio de Patrimonio, IEGPS - CSIC
}

\begin{abstract}
Resumen
Neste artigo trátase de documentar un xacemento arqueolóxico na illa de Ons, concretamente na praia de Canexol (Pontevedra, Galicia) que polos seus indicios arqueolóxicos, podería tratarse dunha factoría de salgadura de época romana destinada á conservación do peixe. Este xacemento que pasou desapercibido ata fai pouco tempo, ven a ocupar o baleiro crono-cultural da illa e que pon de manifesto a ocupación continua deste territorio dende épocas prehistóricas ata a actualidade. $\mathrm{O}$ tempo ven a remarcar a paisaxe mariñeira que caracterizou desde sempre este territorio insular onde os seus recursos mariños foron e seguen sendo un dos elementos fundamentais da economía e formas de vida dos habitantes da illa.
\end{abstract}

\section{Palabras-Clave}

Illa de Ons, Arqueoloxía, Etnografía, Etnoarqueoloxía, Patrimonio Cultural, Recursos mariños.

\begin{abstract}
This paper makes an initial approach to the documentation of an archaeological site in Canexol beach in the Ons islet (Pontevedra, Galicia). According to the evidences documented so far, it looks like a series of fish salting facilities. Tha site, that was previously unknown within the achaeological literature, fills a void in the sequence of occupation of the islet, that should have been inhabited since the earlier prehistory to the present day. At the same time, this site underlines the importance of the sea resources for the live in the islet, very evident in the present day but also remarkable in the ancient times.
\end{abstract}

\section{Keywords}

Illa de Ons, Archaeology, Etnography, Etno archaeology, Cultural Heritage, Sea Resources.

\footnotetext{
${ }^{1}$ Entregado el 10.11.2008
} 


\section{CONTEXTO XEOGRÁFICO E ARQUEOLÓXICO}

O arquipélago de Ons, situado na ría de Pontevedra no concello de Bueu, está conformado pola illa de Ons e Onza ou Onceta (ao N), e os illotes de Centolo (ao S) e Freitosa (ao SW), e forma parte do Parque Nacional das Illas Atlánticas dende o 2002. Este promontorio granítico de forma alargada de dirección N-S, presenta dúas vertentes claramente diferenciadas. A parte orientada ao $\mathrm{E}$, que mira cara á ría de Pontevedra, presenta un perfil rectilíneo cuxo desnivel descende cara ao mar de forma suave, desembocando en diversos areais. A parte orientada ao W, cara ao mar aberto do Atlántico, caracterízase por ser unha costa abrupta e recortada con pequenas enseadas de coidos, acantilados e covas mariñas, tamén chamadas "furnas".

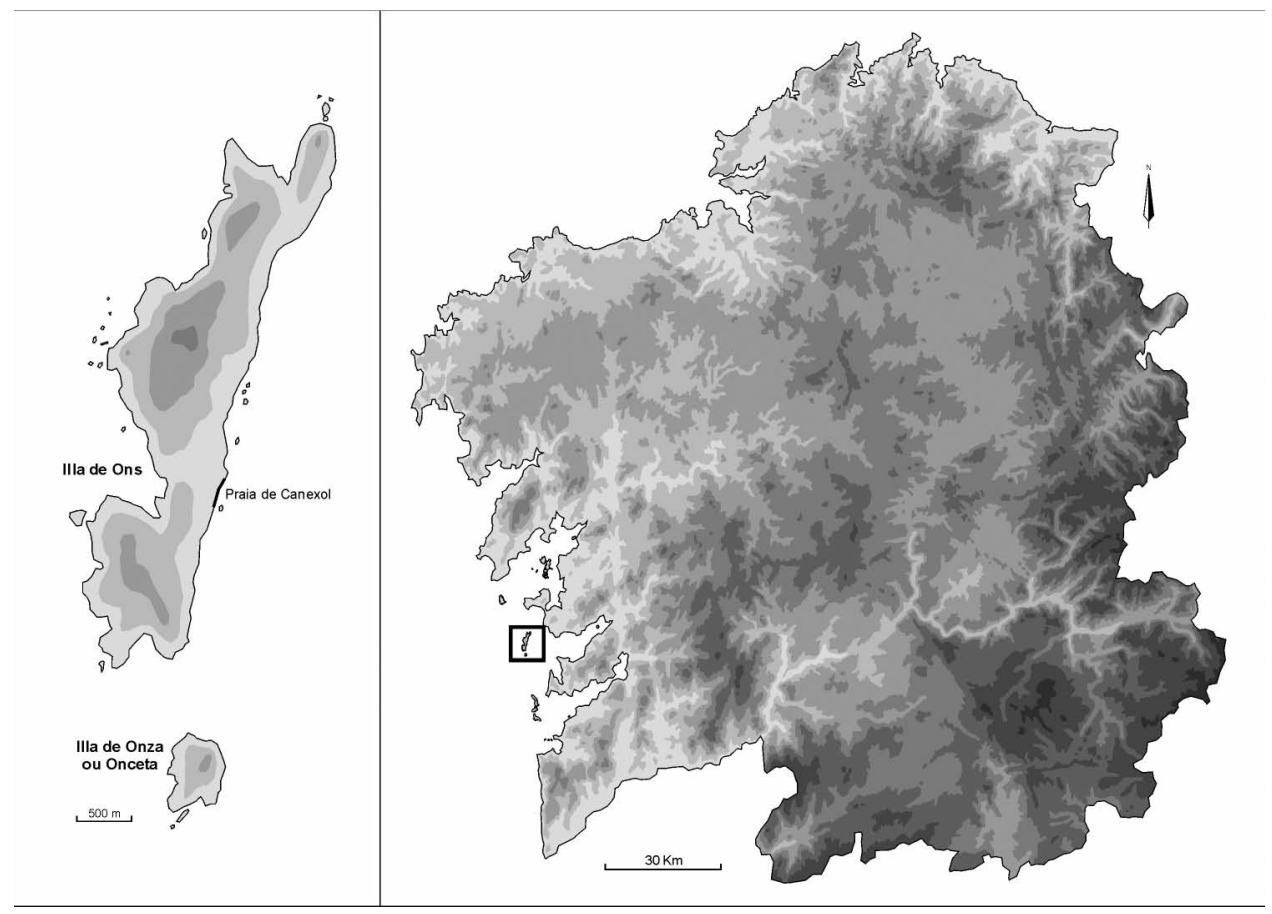

Figura 1. A Illas de Ons no contexto de Galicia (debuxo de Anxo Rodríguez Paz).

O xacemento arqueolóxico de Canexol sitúase sobre o cantil da praia do mesmo nome, emprazada ao SE da illa e na costa orientada cara ao leste. Concretamente ubícase sobre un depósito sedimentario antigo que na actualidade funciona como un cantil activo. 


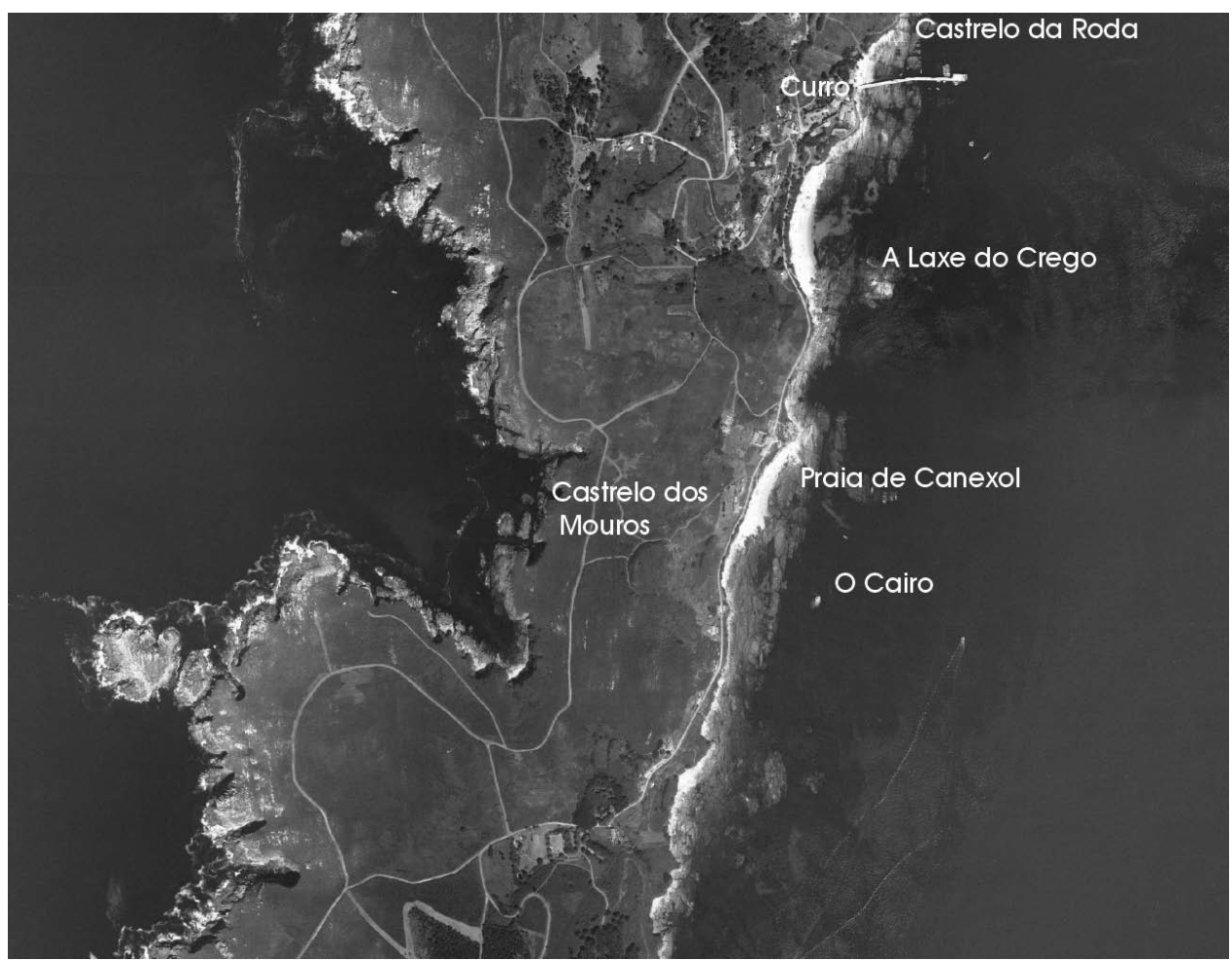

Figura 2. Vista parcial da Illa de Ons onde se sinalan algúns dos toponimos das entidades culturais ás que se fai mención neste traballo.

Dende o punto de vista edafolóxico, segundo M. Costa (1995) gran parte da costa galega está fosilizada por depósitos sedimentarios antigos non consolidados. $\mathrm{Na}$ actualidade, a forma litoral que define a estes depósitos é a dun cantil activo. Pode estar precedido por unha praia ou plataforma litoral, que o protexan dos procesos erosivos mariños ou pola contra caer directamente sobre o mar, mostrando evidencias máis claras de retroceso. Estes depósitos sedimentarios antigos, como o localizado na traspraia de Canexol, están compostos pola intercalación de facies de orixe mariña-eólica e continental, que se suceden de muro a teito, localizándose preferentemente as primeiras, na base do depósito. Soen ter potencias variables, pero dependendo da súa ubicación poden acadar ata os 8-10 metros de espesor. As características morfosedimentarias tenden a ser variables tanto vertical, como horizontalmente. A nivel sedimentario pódense distinguir niveis formados por material fino inorgánico (rico en arxilas, limos e areas, dominando estas últimas), niveis de material fino rico en materia orgánica e acumulacións inorgánicas 
compostas pola intercalación de areas e limos con material de tamaño groso (gravas, cantos e bloques), que se dispoñen de forma aleatoria ou formando estructuras sedimentarias claras. Estas facies significan que estes depósitos rexistran nos cambios sedimentolóxicos variacións claras a nivel de ambientes sedimentarios, que se poden relacionar con cambios nas condicións climáticas.

As datacións radiocarbónicas obtidas para diferentes depósitos localizados na costa Atlántica Galega, permiten enmarcar a súa formación dende o Pleistoceno Final ata o Holoceno. A existencia destas acumulacións na actual liña de costa, ten moita importancia para os estudios de reconstrución de ambientes pasados, debido a que estes depósitos son arquivos de gran valor paleoambiental, que nos informan sobre a evolución e interacción do medio mariño e continental, e particularmente sobre os momentos de cambio no Pleistoceno Final e no Holoceno.

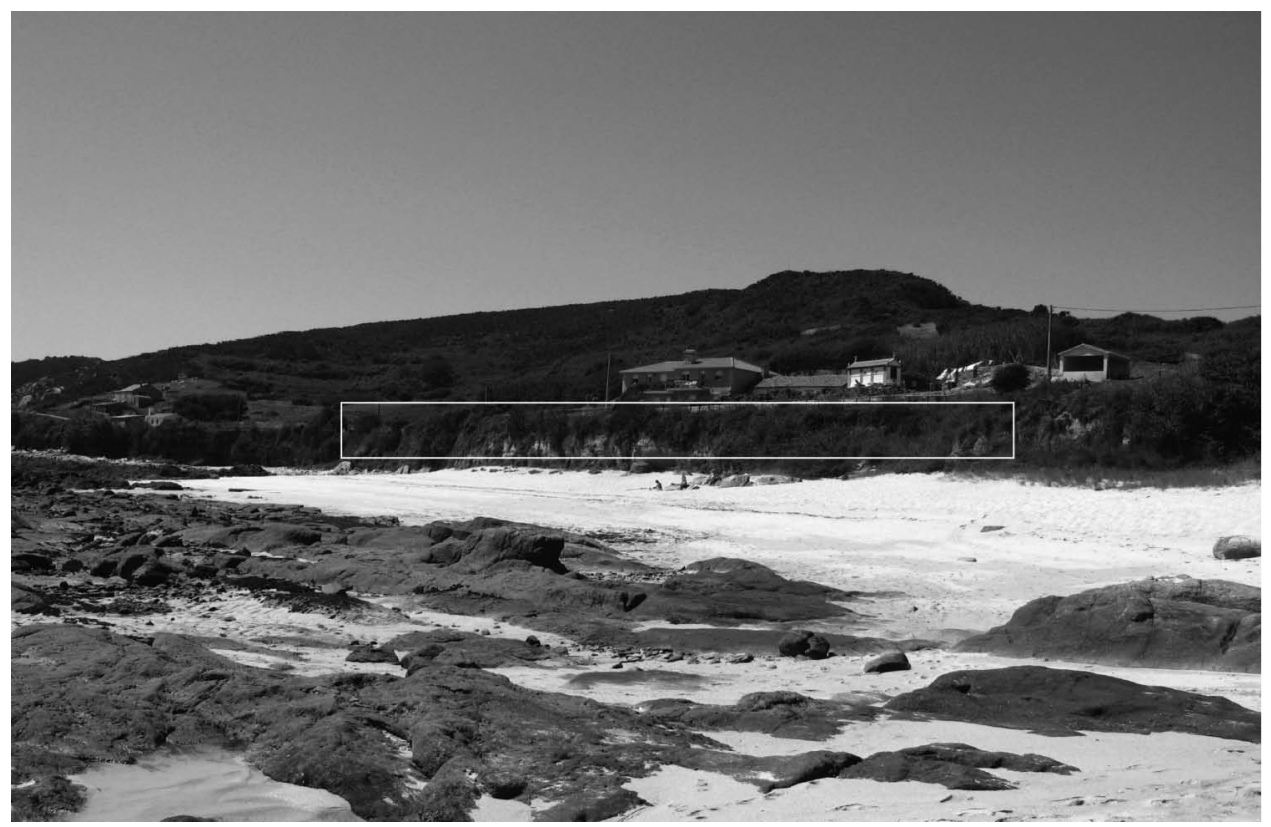

Figura 3. Emprazamento da praia de Canexol, vista cara ao SW. Na imaxe pódese apreciar o cantil onde se atopan as estruturas arqueolóxicas expostas neste artigo.

Ao fondo dístínguese o promontorio pertecente ao castro de "Castrelo dos Mouros".

Polos indicios arqueolóxicos atopados neste cantil de Canexol, poderíamos vincular a este xacemento cunha factoría de salgadura de época romana destinada á conservación do peixe. Este xacemento pasou totalmente desapercibido debido a que na actualidade non se aprecia ningunha evidencia en superficie, sendo só 
visible nos perfís estratigráficos deste cantil. Tampouco se atoparon referencias nos diferentes artigos ou publicacións históricas consultadas sobre a illa. De feito, nin tan sequera existe na memoria histórica das xentes que poboan esta illa (ou se a houbo, desapareceu). Polo tanto, o seu achádego ven a ampliar un pouco máis a lista de entidades culturais existentes na illa de Ons, remarcando a súa importancia como lugar estratéxico e funcional dentro do contexto marítimo da ría de Pontevedra. Tamén ven a ocupar un baleiro crono-cultural da illa como lugar habitado dende épocas prehistóricas ata a actualidade, feito que deixou (e segue a deixar) as súas pegadas na paisaxe.

De forma sintética, poderíamos dicir que, para os primeiros momentos de ocupación na illa de Ons, encontrámonos con moi poucas evidencias arqueolóxicas, non por carecer delas senón pola falla dun estudo arqueolóxico rigoroso. Hai documentados vestixios do Paleolítico, da Idade do Bronce, Idade do Ferro, medieval e moderna ata a actualidade coa pervivenza dunha paisaxe rural tradicional agraria e pesqueira en uso. Deste xeito, ao Paleolítico-Epipaleolítico (11000-5000 a.C.) poderían pertencer un raspador de gneis e unha peza trapezoidal de granito tallado, materiais líticos de especial relevancia, pero dos que se descoñece o seu lugar de procedencia e o seu contexto arqueolóxico. Ambos están depositados no Museo Arqueolóxico de Pontevedra. Para o Neolítico (4300-2600 a.C.) Xurxo Lourenzo, no seu Diario Arqueolóxico (1934), di que na súa corta viaxe pola illa tiveron noticias de mámoas e de "camiños cubertos" aínda que non puideron ser comprobados. Álvaro das Casas (1934) tamén fala de presuntas mámoas e de ósos humanos descubertos en paraxes distantes do actual cemiterio. Á Idade do Bronce (2600-900 a.C.) pertencerían dous machados de talón que, ao igual que o material anterior, tamén están descontextualizados (Vilas 2005: 149). Á Idade do Ferro pertence o castro "Castrelo dos Mouros" ou "Castro do Alto" situado no Alto de Altura (97 m sobre o nivel do mar). Descríbese coma un recinto cun antecastro separado por un foso. Aquí atópase "A Cova dos Mouros", lugar que aglutina moitas das lendas da illa. Pola bibliografía consultada, hai referencias da posible existencia dun segundo castro situado na zona norte da illa denominado "Cova da Loba" e na que, segundo as fontes, apareceron restos de materiais cerámicos e concheiros. Xurxo Lourenzo dalle o nome de "Coto da Coba do Lobo" e di que ten tradición da existencia de vivendas calificándoo, por outra banda, como o máis interesante da illa.

Recentemente, e produto do traballo realizado para a elaboración deste artigo, documentáronse evidencias de ocupación romana. Aínda que a escaseza de datos non o permitan concretar, poderían estar asociados a unha explotación de recursos mariños situada sobre o cantil de Canexol. 
De época medieval é "A Laxe do Crego", sepulcro antropomorfo escavado nunha das rochas máis destacadas da praia de Area dos Cans e á que se accede en baixa mar. E xa en época contemporánea están rexistradas dúas fortificacións, unha coñecida como "Castelo da Roda" en Curro, e unha segunda situada no barrio de Pereiró, ambas construídas no 1810.

Finalmente, dentro deste patrimonio construído debemos ter a paisaxe agraria tradicional, que afortunadamente aínda consérvase e que ven a remarcar a insularidade da illa, debido a que os longos temporais de inverno facían imposible vivir cara ao mar e, polo tanto, limitaban a entrada de produtos da península. E a paisaxe mariñeira, paisaxe que, como veremos, dotaba, e o segue facendo, de parte dos recursos aos habitantes da illa.

\section{DESCRICIÓN DO XACEMENTO DO AREAL DE CANEXOL}

O xacemento arqueolóxico de Canexol esténdese ao longo de aproximadamente $300 \mathrm{~m}$ do cantil da praia do mesmo nome, e é visible só na parte superior desa parede, non apreciándose ningunha evidencia en superficie. Este xacemento está orientado cara ao E. Entre a vexetación que cubre parte do cantil do areal pódense distinguir varias estruturas de distinta tipoloxía.

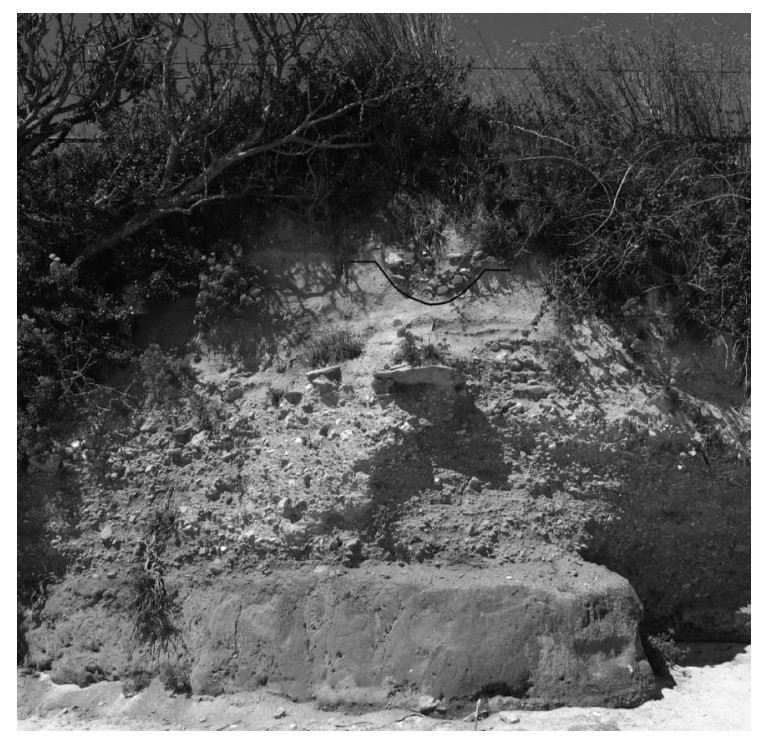

Figura 4. Vista xeral dunha parte do cantil de canexol onde se aprecia o amplo depósito antigo sedimentario sobre o que se escavou unha fosa de orixe antrópica. 
De $\mathrm{N}$ a S, o primeiro elemento antrópico que se aprecia no perfil e unha fosa en forma de "U" de mediano tamaño, escavada no xabre, con pedras de pequeno e mediano tamaño na base da mesma, fundamentalmente no lado norte, e selada por unha amplo paquete de terra moi homoxéneo e que tamén parece que está presente ao longo do perfil do areal.

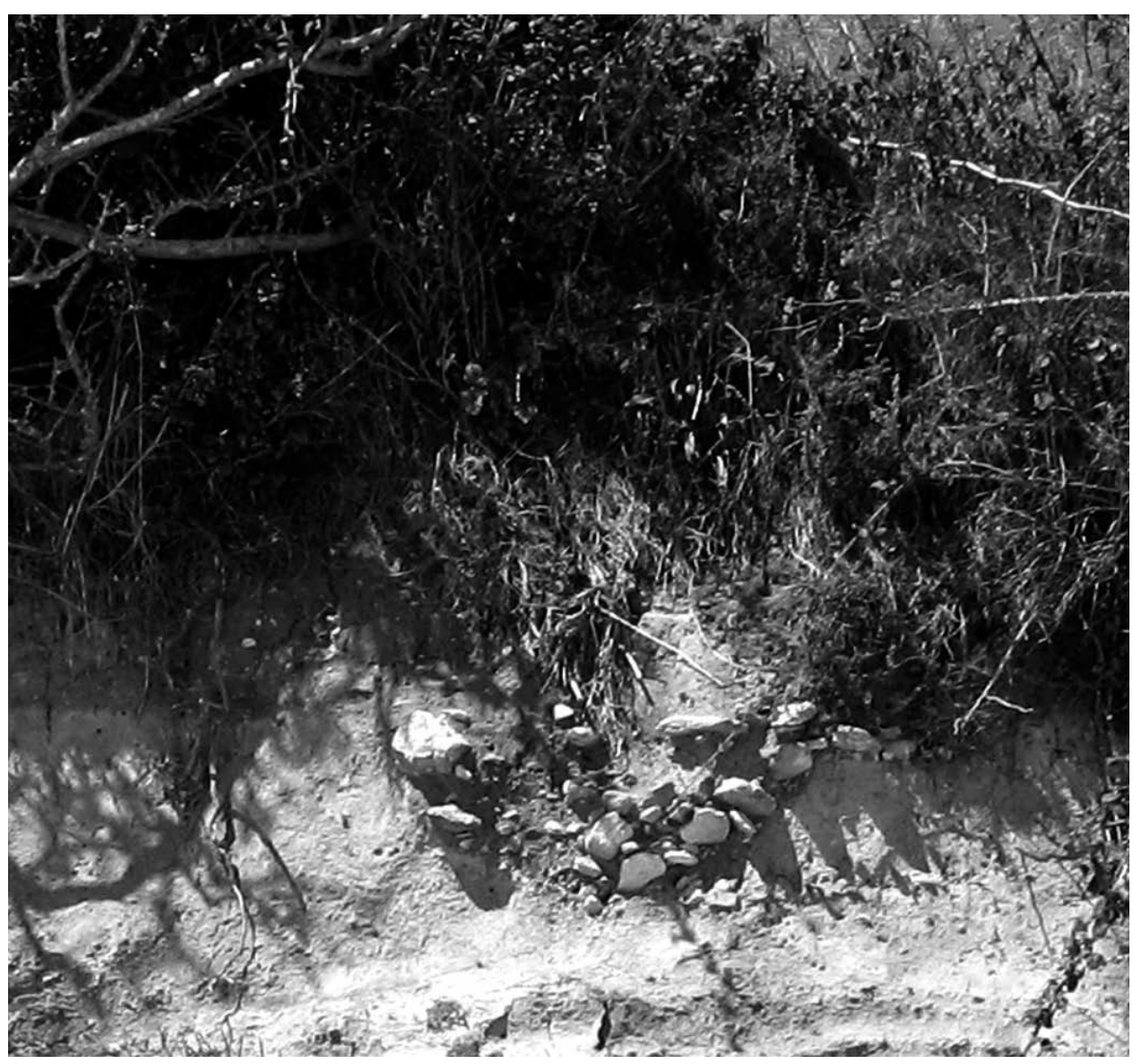

Figura 5. Detalle da fosa escavada no xabre.

A poucos metros e cara ao $\mathrm{S}$ apréciase parte dun muro feito con pedra de granito coas súas caras traballadas. Aquí, sobre a estratigrafía natural do perfil pódese distinguir un solo a modo de cimentación, realizado cunha argamasa a base de seixo moi fragmentado e cal de uns $3 / 4 \mathrm{~cm}$ de grosor (opus signinum), que tamén se aprecia nas diferentes partes do perfil estratigráfico do areal. 


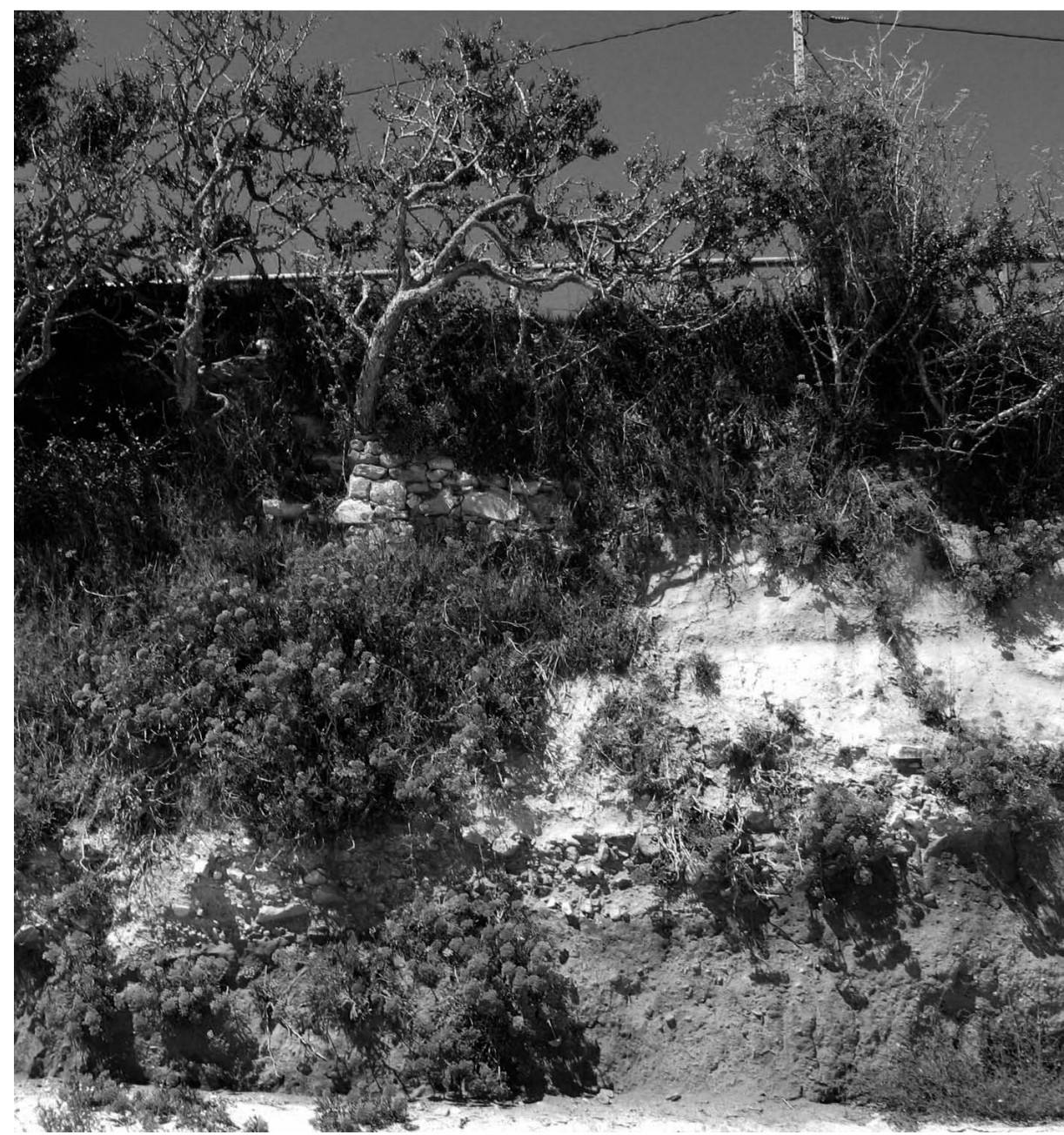

Figura 6. Detalle do cantil onde se pode ver parte da estrutura dun muro antigo.

Máis ao sur, distínguense unhas laxes de granito de gran tamaño dispostas de xeito horizontal a modo de pontella, aínda que o seu oco está recheo de cachotes de pedra granítica e de cantos rodados. Neste caso, estarían así dispostas para salvar un desnivel. Pero coa abundante vexetación non se pode apreciar con certeza a que tipo construtivo se pode corresponder.

A partir desta estrutura, e cara ao $\mathrm{S}$, é onde se localizan os vestixios máis visibles deste xacemento, os máis evidentes para poder vincular este lugar cunha factoría de salgadura de peixe. 
O APROVEITAMENTO DO MAR AO LONGO DO TEMPO.

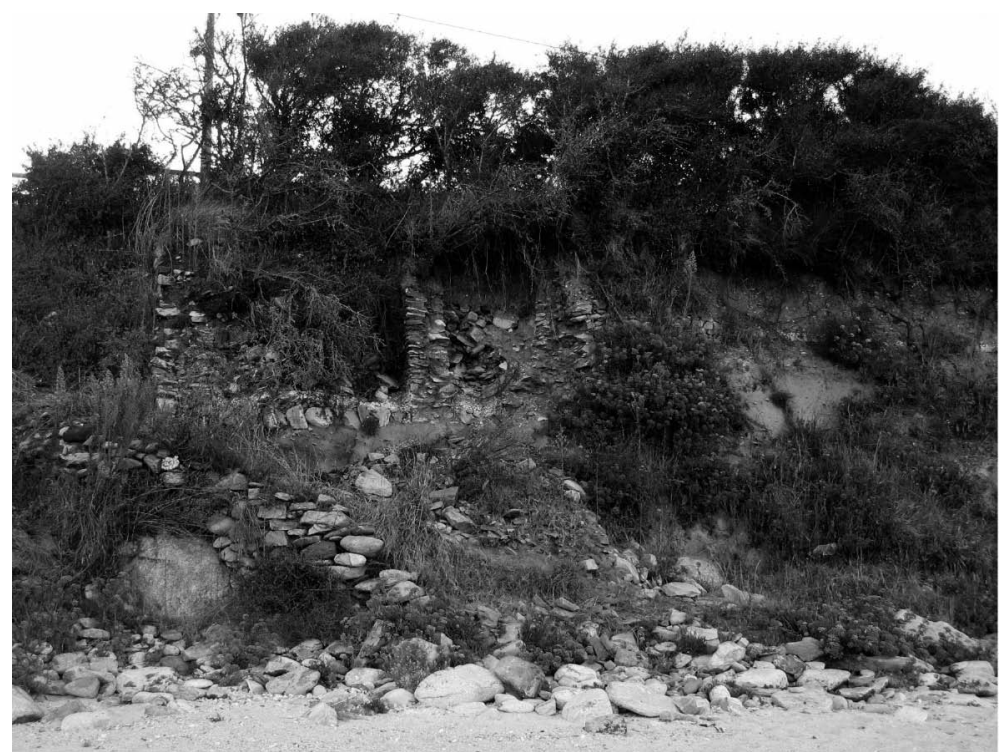

Figura 7. Vista xeral das estruturas arqueolóxicas máis visibles e identificativas do xacemento de Canexol. Pola súa forma, disposición e materiais poderían vincularse a unha antiga factoría de salgadura.

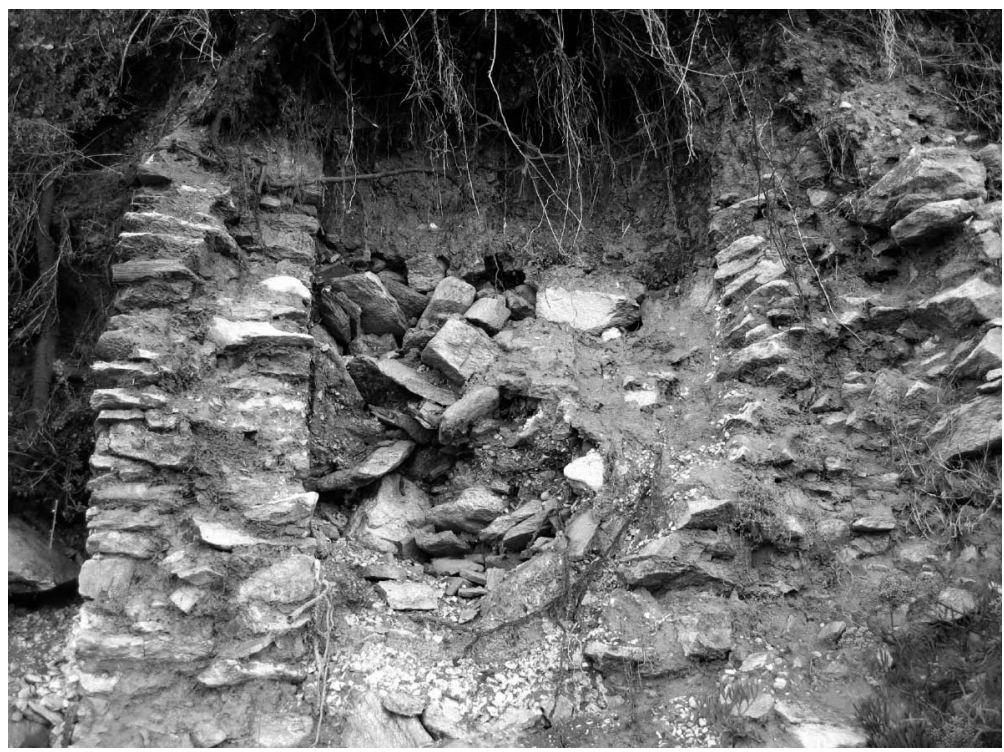

Figura 8. Detalle dos muros, posiblemente correspondentes a unha pía de salgadura. Apréciase a colmatación destas estructuras por diferentes materiais en distintas posicións. 
Deste xeito, sobre o horizonte natural de xabre regularizado e horizontal, disponse un leito de cantos rodados e pedras de formas irregulares tendentes a forma cuadrangular. Sobre este leito, levántanse tres muros paralelos distantes uns dos outros 1,5 m aproximadamente. Son muros de dobre cara, compostos por pedras de granito de formas cuadrangulares e pouco grosor, dispostas unhas enriba das outras a modo de lousetas.

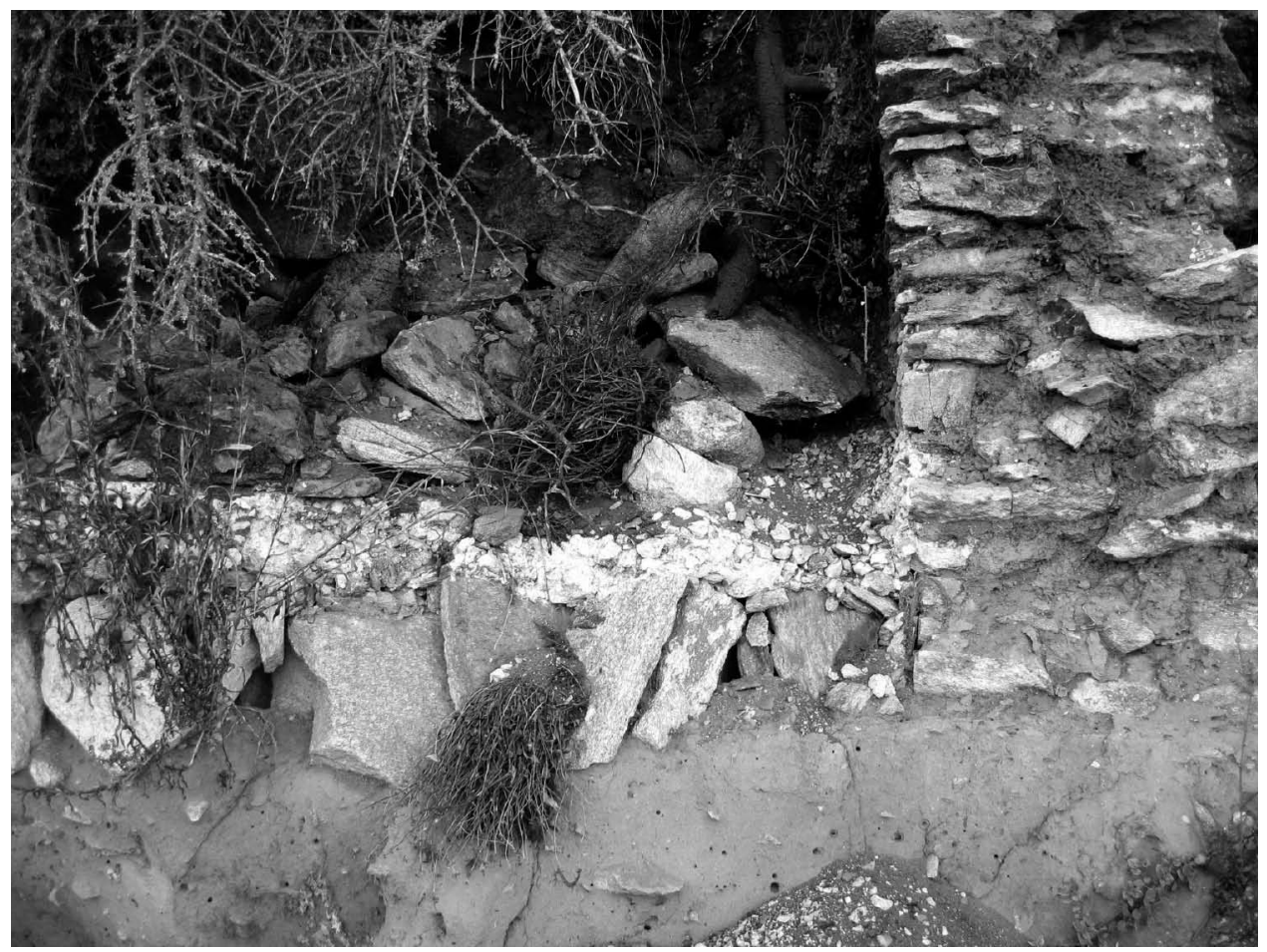

Figura 9. Base dunha pía ou depósito revestida con opus signinum.

A base e a parte inferior dos muros caracterízanse por ter un revestimento composto por un morteiro realizado a base de seixo moi fragmentado e cal, compactado e aprisionado. É o chamado opus signinum, morteiro utilizado para impermeabilizar construcións relacionadas con estructuras hidráulicas ${ }^{2}$ como canais, estanques, cisternas, piscinas, etc... Este depósito xa aparece caracterizado en tramos anteriores.

${ }^{2}$ Destacar que o seixo está composto por dióxido de silíceo que funciona como un desecante natural que aisla de humidade no lugar no que se atopa. 


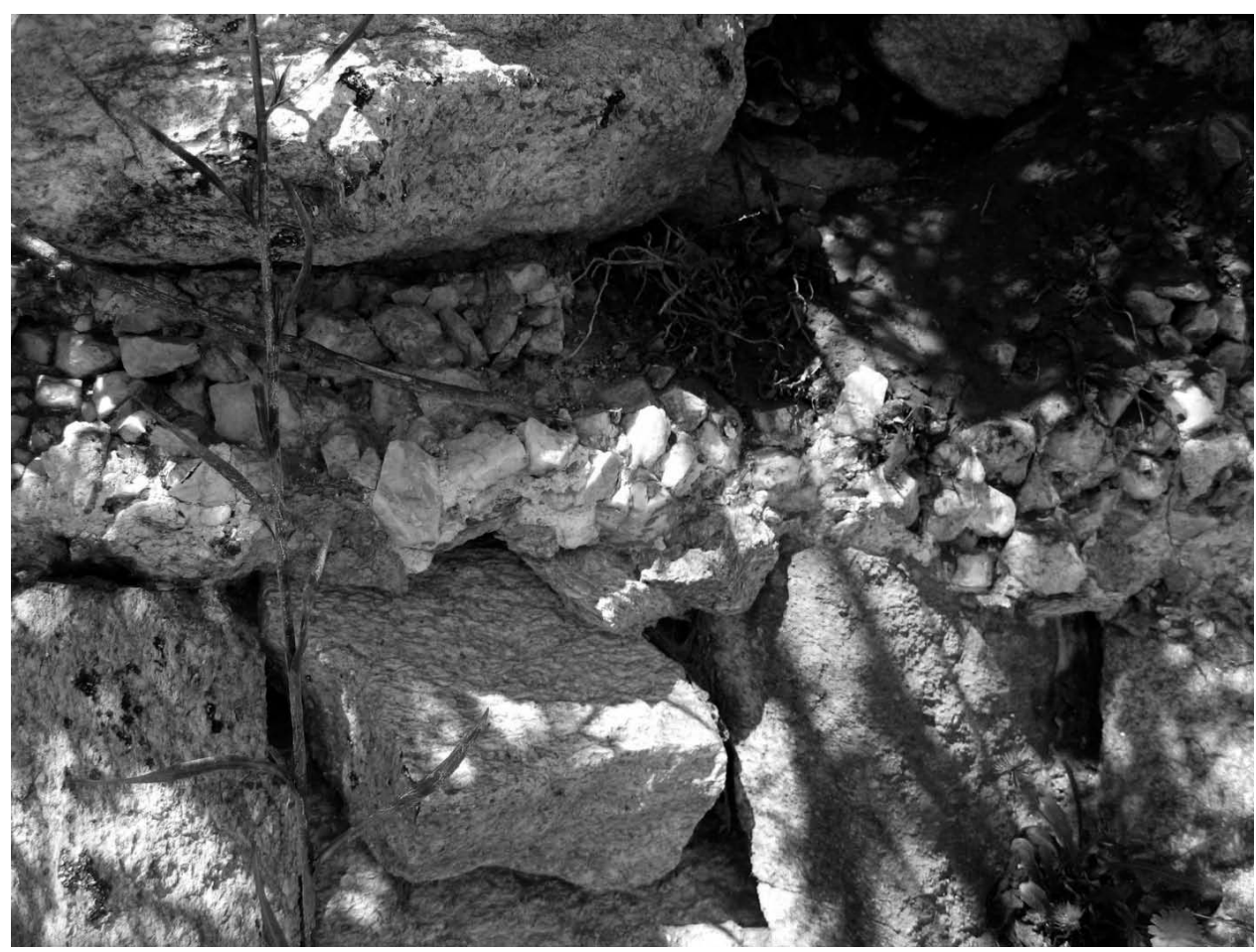

Figura 10. Detalle da cimentación revestida co opus signinum.

Polo que se pode apreciar, e por comparación co rexistro arqueolóxico documentado noutros xacementos de similares características, parece que estes muros formarían parte duns contenedores ou pías para a salgadura do peixe. Cada unha destas estruturas aparecen colmatadas por pedras, tégulas (tellas planas de reborde) e ímbrices (tellas curvas) ${ }^{3}$ en diferente grao de rodamento e fragmentación, carbóns de diferentes tamaños, ósos procedentes de mamíferos e de peixes, pudendo ser froito tanto do seu antigo uso mesturado cos derrubes ou/ e da amortizacións destas estruturas como vertedoiro. Sobre estas estruturas distínguese un amplo paquete de terra non moi orgánica e de gran fino de características similares ao que aparece selando a fosa que se describiu en primeiro lugar, o que

${ }^{3}$ Estes materiais de cubrición son sinais evidentes de romanidade xa que o seu uso desaparece a principios da Idade Media sendo sustituídos pola cobertura realizada só con imbrices dispostos en fiadas paralelas e alternando o dereito e o revés, sistema que perdura ata hoxe. Por outra beira, a tégula non só foi utilizada para a cuberta senón que tamén se utilizou para pavimentos, canalizacións, tumbas, etc. funcións que parecen que se alongaron no tempo xa que aparecen en rexistros altomedievais. 
leva a pensar que parece que foi depositado todo ao mesmo tempo coa intención de cubrir estes diferentes elementos construtivos e aplanar o terreo para darlle un novo uso.

Uns metros ao $\mathrm{S}$ distinguimos un derrubo recente provinte dun muro de contención tamén realizado con cachotería de granito. Se seguimos observando o perfil na mesma dirección, seguiremos apreciando estruturas de diversa índole pero, como xa se resaltou máis arriba, debido á abundante vexetación e á altura que adquiren estas no perfil, non é posible caracterizalas con precisión.

Procedentes dos derrubes e da erosión constante á que está sometida esta parede do areal, longo da praia e en superficie, distínguense restos materiais construtivos procedentes destas edificacións como tégulas, ímbrices, pedras de formas escuadradas, así como tamén algunhas pezas de cerámica das que se recolleron varios fragmentos para poder facer unha análise algo máis pormenorizada.

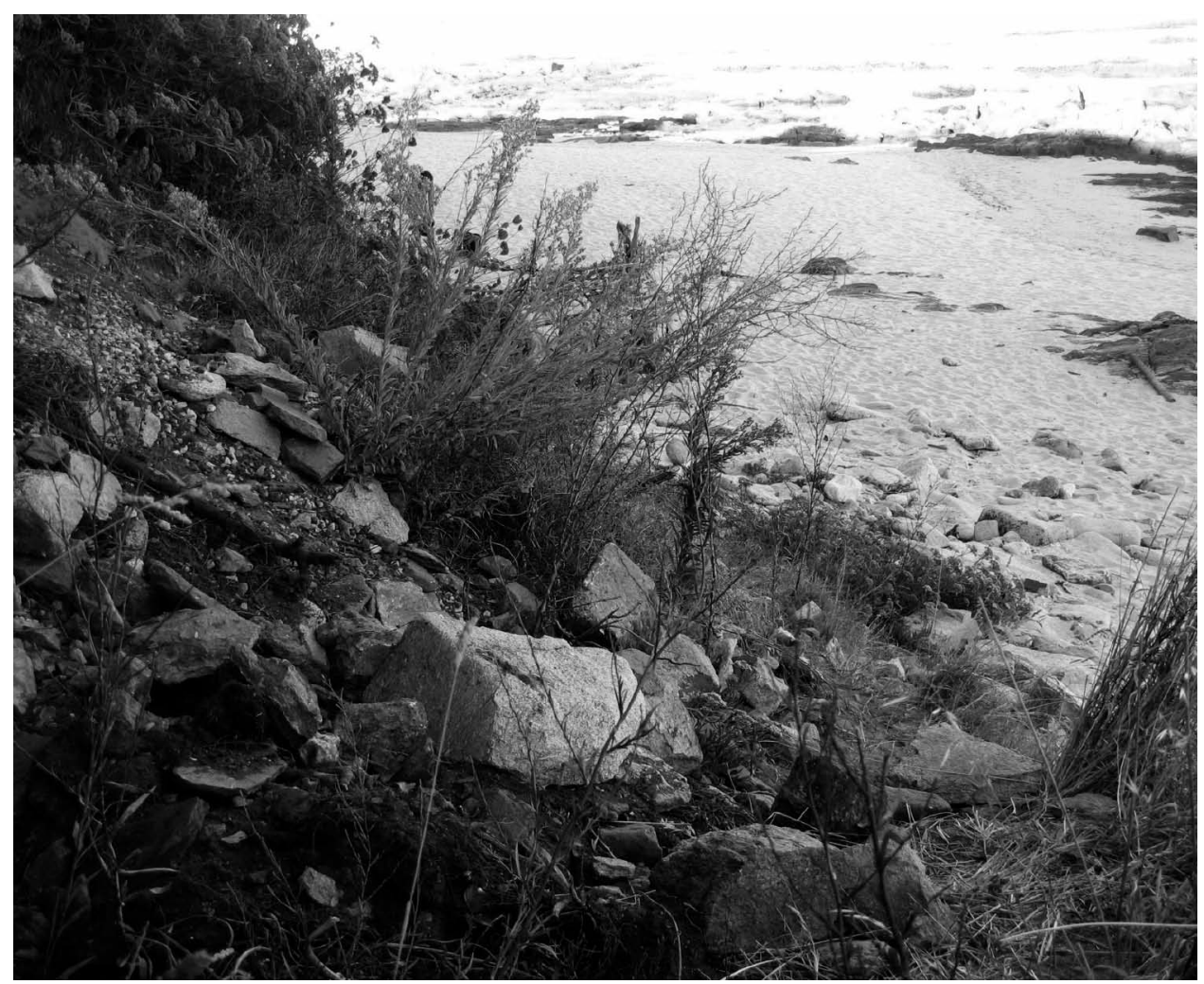

Figura 11. Derrubos no areal froito da constante erosión, onde se poden apreciar diversos materiais cerámicos e de construción. 


\section{O MATERIAL CERÁMICO ${ }^{4}$}

O conxunto está formado por tres fragmentos cerámicos. Dous de factura claramente indíxena e un fragmento de ánfora romana.

No que se refire aos dous fragmentos de tradición indíxena hai que sinalar que trátanse dun fragmento de bordo e un fragmento de panza. $\mathrm{O}$ fragmento de bordo defínese tipoloxicamente como tipo Cíes. Caracterízase por un labio engrosado. Este tipo de cacharro relaciónase coa tradición alfareira das Rías Baixas. Desde un punto de vista cronotipolóxico o período de maior desenvolvemento desde tipo cerámico dáse entre os séculos IV a.C-II a.C. aínda que hai pervivenzas no século I a.C. No que se refire ás pastas deste fragmento de bordo trátase dunha pasta de fractura irregular, con inclusións correctoras de tipo granítico e na que destaca tamén a ampla presencia de chamotas. A proporción das inclusións correctoras é abundante e o grao é groso. As arestas da fractura son vivas e non presentan restos de feluxe nas pastas. A cor das paredes é regular, presenta unha coloración marrón clara. O interior da pasta é dunha coloración grisácea presentando a sección unha combinación cromática tipo "sándwich". O acabado caracterízase por ter un alisado moi basto. A cocción é redutora e é posible que se empregase o torno lento.

O outro fragmento de cerámica de tradición indíxena é un fragmento de panza que non se pode adscribir tipoloxicamente a ningunha tradición alfareira. Desde o punto de vista cronolóxico é unha cerámica que se vincula á Idade do Ferro. No que se refire á pasta deste fragmento hai que dicir que trátase dunha pasta cunha proporción de inclusións correctoras de orixe granítica moi abundantes. Cambia con respecto ao anterior fragmento na materia prima, xa que a orixe das inclusión correctoras desta panza ven da praia, ou alomenos, dunha praia. Aprécianse grande cantidade de fragmentos de mica e feldespato. A cor das pastas é homoxénea. No exterior das pastas presenta unha coloración alaranxada e no interior grisácea. A combinación cromática da sección é igual que o anterior fragmento de tipo "sándwich". O acabado defínese como un alisado basto, se ben hai que dicir que este fragmento está moi rodado á diferencia do anterior fragmento. A cocción é redutora.

\footnotetext{
${ }^{4}$ A descrición da cerámica, así como as hipótesis procedentes desta parte da cultura material foron realizadas polo arqueólogo Marco Antonio Rivas Nodar, adscrito ao Laboratorio de Patrimonio, Paleoambiente e Paixase (IIT, USC).
} 


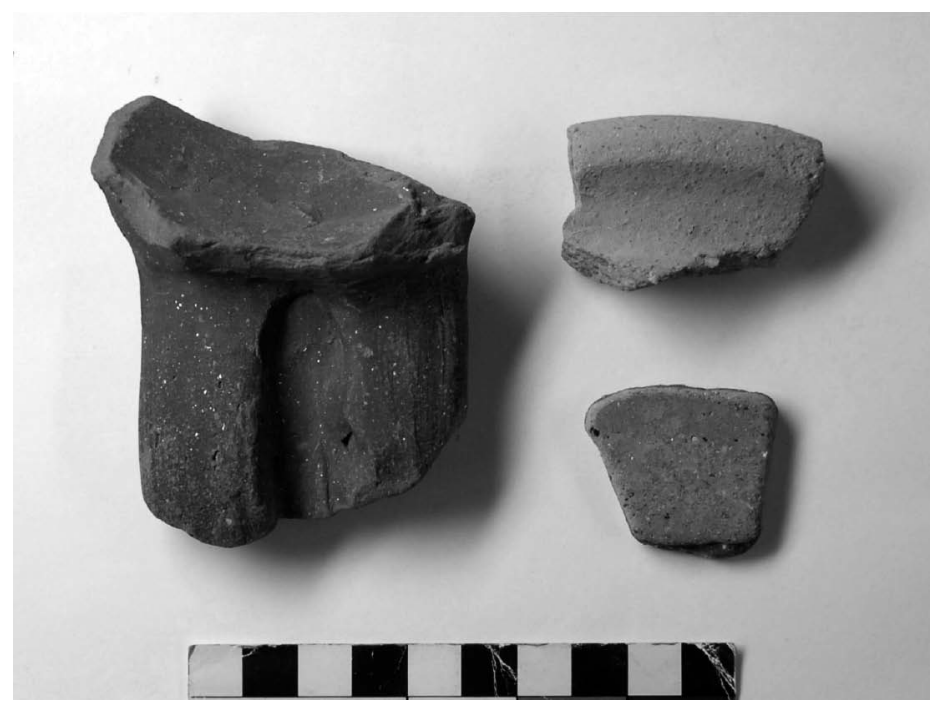

Figura 11. Conxunto de materiais cerámicos recuperados no areal de Canexol procedentes das estruturas arqueolóxicas situadas no cantil.

O terceiro fragmento procede dunha ánfora que, desde o punto de vista tipolóxico, defínese como unha Dressel 2-4. Trátase do arranque dun asa e parte do colo do cacharro. Defínese como un ánfora de colo troncocónico e labio esvasado. Presenta unha acanaladura na parte superior da asa. A súa cronoloxía sitúase entre o século II a. C e I d. C. A pasta é de cor roxiza-alaranxada. Presenta inclusións correctoras de orixe cuarcítico en escasa proporción e de gran fino. Hai que destacar a presencia de grandes fragmentos de cuarzo na zona de contacto entre o colo e a asa. Finalmente destacaremos que esta zona presenta dixitalizacións producidas no momento de unir a asa ó colo.

\section{PROBLEMÁTICA ARQUEOLÓXICA. O MAR COMO RECURSO NA COSTA GALEGA}

A descrición e análise das estruturas localizadas na praia de Canexol lévanos a pensar que, por analoxía co rexistro arqueolóxico documentado noutros xacementos de similares características emprazados ao longo da costa parece que, en conxunto, formarían parte dunha factoría romana de salgadura, ou polo menos dun asentamento con algunha instalación de salgadura, localizado nas proximidades do castro e na beira do areal. 
Nese sentido, hai que ter en conta os estudos específicos que demostran que a pesca e o marisqueo alcanzaron unha importancia considerable xa na época castrexa como un alimento base da subsistencia do seus habitantes. O que non quere dicir que os recursos mariños non se tiveran en conta dende épocas anteriores. Pero si é certo que nestes momentos é cando este rexistro arqueolóxico é moito máis evidente e abundante. A pesca practicaríase nas augas próximas á costa, utilizando anzois e redes, como o confirman os restos paleontolóxicos dos concheiros e os artefactos de pesca atopados nos castros ${ }^{5}$.

Dende o punto de vista historiográfico, o primeiro estudo sobre este tema das salgaduras data de mediados do século pasado cando se escava Troia, en Portugal, iniciándose así unha traxectoria no estudo das pesquerías e das salgaduras. En 1965 será cando apareza un traballo de Ponsí do que arrincarán o resto dos estudos. Traballos como o de Fernández Ochoa (1994) se refiren máis ao N e NW peninsular. Tamén están os traballos de Naveiro López (1991), Castro Carrera (1992), Vázquez Varela (1992) entre outros.

A tradición da conserva do peixe en salgado parece que ven dos púnicos, no século VI a.C. e serán os romanos os que recollerán esa tradición alcanzando con eles os niveis máis altos de manufacturación e comercio. As evidencias arqueolóxicas sobre a industria de salgadura establecen no $\mathrm{S}$ da península a clave, a partires de onde se estendeu, en época romana, pola costa atlántica (Naveiro 1991: 101). As importantes factorías que se concentran en torno aos estuarios do río Sado e o Tejo parecen facer de ponte para aproxima-lo NW á área básica destas producións. Estímase que o establecemento masivo prodúcese entre o século I a.C. e II d.C. sendo no século III e IV d.C cando se abandona esta práctica.

Dende o punto de vista do rexistro arqueolóxico, nos últimos anos rexistráronse importantes achádegos arqueolóxicos romanos costeiros vinculados á explotación dos recursos mariños (Suárez 2003) que permiten valorar a importancia desta producción no contexto de Galiza. Documentáronse factorías de salgadura no Fiunchal (Alcabre, Vigo), en Punta Borralleiro (praia do Cocho, Alcabre, Vigo), no núcleo urbano de Vigo. Aquí, dentro da área do xacemento da rúa Pontevedra /Areal localizáronse salinas con varios niveis de ocupación. No extremo E da praia de Barra (Cangas) menciónase a presencia de catro lagares de salgadura dispostos en bloque e fabricados en argamasa de tipo romano (Bouza et al. 1971: 65). A

\footnotetext{
${ }^{5}$ Para este apartado consultar o artigo realizado por Vázquez Varela et al. (1992) no que se presentan datos e interpretacións arqueolóxicas e paleontolóxicas sobre a pesca no mundo castrexo e romano en Galiza, complementadas á súa vez, con explicacións baseadas en estudos etnoarqueolóxi$\cos$.
} 
Igrexiña (Nerga, Cangas), xacemento relacionado con salinas que abastecerían as instalacións romanas próximas. En Bueu, no barrio de Pescadoira, onde se constatou a existencia dun conxunto de estruturas relacionadas cunha fábrica de salgadura, e de olería posiblemente asociados a unha villa. En Adro Vello (San Vicente do Grove) tamén se documentou una pequena fábrica de salgadura onde as especies piscícolas integrantes da ultima capa de salgado correspóndense con sardiñas e xurelos entre outras. No porto de Vilagarcía de Arousa, na que se documentaron estruturas relacionadas coa salgadura de peixe. E, máis ao $\mathrm{N}$, en Cariño, Espasante (Ortigueira), Bares (Mañón) ou na praia de Area en Viveiro, Lugo, entre outras.

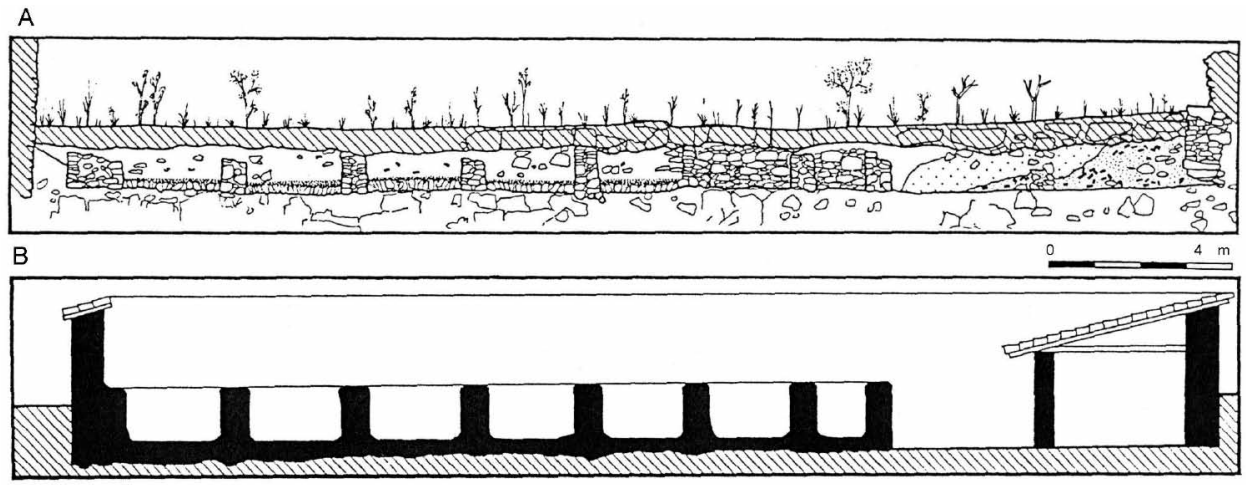

Figura 13. Debuxo da factoría de salgadura de Cariño, Ferrol. O superior correspóndese co corte estratigráfico do perfil costeiro e o inferior coa reconstrución hipotética das estruturas (Naveiro 1991: 104). Polo que se pode apreciar, estas estructuras son moi similares ás atopadas en Canexol.

\section{APROXIMACIÓN ÁS CARACTERÍSTICAS FORMAIS DAS FACTORÍAS DE SALGADURAS}

Por norma xeral, as factorías de salgaduras de época romana, aséntanse na costa, preto das praias, en lugares abrigados que puideran funcionar como embarcadoiros naturais para os pescadores. O seu emprazamento tiña en conta fundamentalmente tres factores: ter bancos de pesca para o seu subministro, a proximidade a regos para o aprovisionamento de auga doce para limpar o peixe e para as fases do salgado, e dispoñer de salinas próximas para abastecerse de sal, imprescindible para o proceso de conservación ${ }^{6}$.

\footnotetext{
${ }^{6}$ Estes factores tamén foron tidos en conta para a construcións de fábricas de salgadura en época moderna e contemporánea
} 
As pías de salgadura, cadradas ou rectangulares, son o elemento fundamental destas instalacións, variando o seu tamaño segundo a capacidade de produción da factoría. Segundo o rexistro, poden ser rupestres (onde as pías están escavadas na rocha, polo que non necesitan ningún revestimento impermeable, tendo unha distribución máis anárquica xa que se adapta á configuración da rocha), ou de obra, onde os estanques están formados por muros de cachotería que se cruzan perpendicularmente nun trazo reticular e impermeabilizados con una capa de morteiro de cal e seixo.

Os derrubes documentados nalgúns destes xacementos inclinan a pensar que parte do recinto ocupado por estas estruturas estaría cuberto por un tellado sinxelo a base tégulas e ímbrices.

Como paralelo etnográfico tomamos as descricións feitas por Xaquín Lorenzo (1962) sobre un edificio de salgadura contemporáneo onde resalta a importancia desas instalacións para a economía galega de mediados do século XX. Describe a construción emprazada nun patio rectangular con alpendres ao redor, podendo estar cuberto na súa totalidade con tellados descansando en columnas ou pés dereitos. As pías, pilos ou lagares feitos en cachotería miden 2, $5 \mathrm{~m}$ de lado por 1, $5 \mathrm{~m}$ de fondo, variando acordo co tamaño da instalación e van provistos de tapas de madeira ou batiportes que descansan nuns pontóns que atravesan as pías. En cada fábrica hai tamén un depósito para o sal, almacéns para as barricas, redes e ata unha carpintería para facer o instrumental.

Segundo Campos (1996) o proceso de salgadura en época romana realizábase torando o peixe para despois introducilo nas pías que contiñan auga cunha determinada proporción de sal, manténdoo así durante un tempo ao sol ata que estivera listo para ser consumido ou comercializado ${ }^{7}$. Xaquín Lorenzo describe, unha forma máis complexa para o proceso artesanal da salgadura da sardiña ou xurelo, elaborado nalgunhas das factorías galegas da súa época. Explica que o peixe traíase en pequenos cestos -os paxes- que contiñan arredor de douscentos cincuenta pezas cada un. Este peixe deitábase directamente nos pilos, alternando un paxe de sardiñas cunha patela de sal; a patela é un cesto que contiña unhas vinteoito libras dise produto. Botábanse de xeito que o peixe e o sal estiveran ben mesturados. Unha vez cheo o pilo cubríase cunha grosa capa de sal e finalmente tapábase coa patiporte. O peixe tíñase neste estado, chamando a chanca, durante un tempo que variaba de trece días no verán a quince no inverno. Rematado este tempo rompíase

\footnotetext{
7 A salgadura é o proceso fundamental para a conservación do peixe. Pero tamén elaborábanse outros produtos derivados del como as salsas entre as que destaca o garum; e da moenda do seu esqueleto obtíñase fariña para o alimento dos animais ou como abono para os campos de cultivo.
} 
a capa de sal formada enriba do peixe e, por ese burato, botábanse sete ou oito portadeiras (medio barril de madeira con dous paos atravesados para coller entre dúas persoas) de salmoira. A salmoira ou moira ${ }^{8}$ é auga saturada de sal feita noutro pilo. Finalmente, remexíase ben para que todo o peixe se empapara ben coa mestura. Este era o proceso fundamental e do que se collía o nome para denominar o conxunto do das tarefas (Lorenzo 1962: 441-51).

\section{HIPÓTESES ARQUEOLÓXICAS. O MAR COMO RECURSO OLVIDADO}

Ante os datos presentados, nos que o establecemento romano na illa semella bastante probable, parece unha realidade que na illa houbo unha continua ocupación desde tempos moi lonxanos, como así o testemuñan as evidencias documentadas ata a actualidade, posiblemente con momentos de maior ou menor intensidade, debido a unha serie de motivos, ben sexan sociais, económicos ou culturais e que, polo momento, por unha falla de estudos históricos, arqueolóxicos, antropolóxicos, etnográficos e paleoambientais non é posible pescudar.

Normalmente, nestas fases de ocupación tense en conta unicamente a cultura material produto desa ocupación, pero case nunca se pensa no factor social, en como eran ou de que vivían esas comunidades, e se algo se tende a pensar é case de forma instantánea cara aos recursos agrarios e non cara ao mar, a pesares de estares arrodeados del, e de seguir sendo o recurso motor de moitas das comunidades costeiras.

Se temos en conta o contexto arqueolóxico, Castrelo do Mouros (97 m de altura), atópase a uns $90 \mathrm{~m}$ ao $\mathrm{W}$ do areal de Canexol, coas terras de labor en forma de amplos aterrazamentos en suave pendente situados na ladeira orientada ao leste do castro. Deste castro sabemos moi pouco agás da súa forma e dimensións e das lendas asociadas. Descoñecemos a súa cultura material e polo tanto todas as interpretacións que derivarían da súa análise, o seu espazo doméstico e as súas áreas de captación de recursos agrarios e gandeiros e, sobre todo, a súa relación co mar. Este último aspecto cobra relevancia ante o rexistro documentado en Canexol. É evidente o carácter estratéxico do emprazamento de Canexol encol do mar funcionando como área de explotación de recursos dende alomenos a época castrexa (o que explicaría a existencia de material castrexo na praia) é continuaría neste lugar con maior incidencia en época romana ata pasados uns séculos e caer

\footnotetext{
${ }^{8}$ Xaquín Lorenzo suxire que deste nome derivaría o topónimo do barrio pontevedrés da Moureira.
} 
no desuso. Pero o certo é que non dispoñemos de datos suficientes como para valorar esta secuencia de ocupación. O carácter estratéxico ven acentuado pola ideonidade do emprazamento deste xacemento para funcionar como unha factoría de peixe. Sitúase sobre a praia de Canexol, lugar que na actualidade segue funcionando como embarcadoiro natural (especificamente a parte norte do areal) utilizado polos mariñeiros hoxe en día. De feito eles din que o topónimo de Canexol derivaría de canle explicando que nesa parte da praia fórmase un canal natural que facilita a entrada e saída de pequenas embarcacións. Tamén hai auga doce cerca, hoxe en día captada por un lavadoiro.

Dende o punto de vista da cultura material recollida, non cabe dúbida que un conxunto cerámico representado por tres fragmentos cerámicos non aporta ningún tipo de conclusión. É preciso subliñar que os materiais, ao aparecer en superficie, non poden vincularse claramente con algunhas das estructuras anteriormente descritas xa que tamén poden estar relacionados directamente co castro posto que se este se atopa a moi poucos metros desta parte de costa ${ }^{29}$.

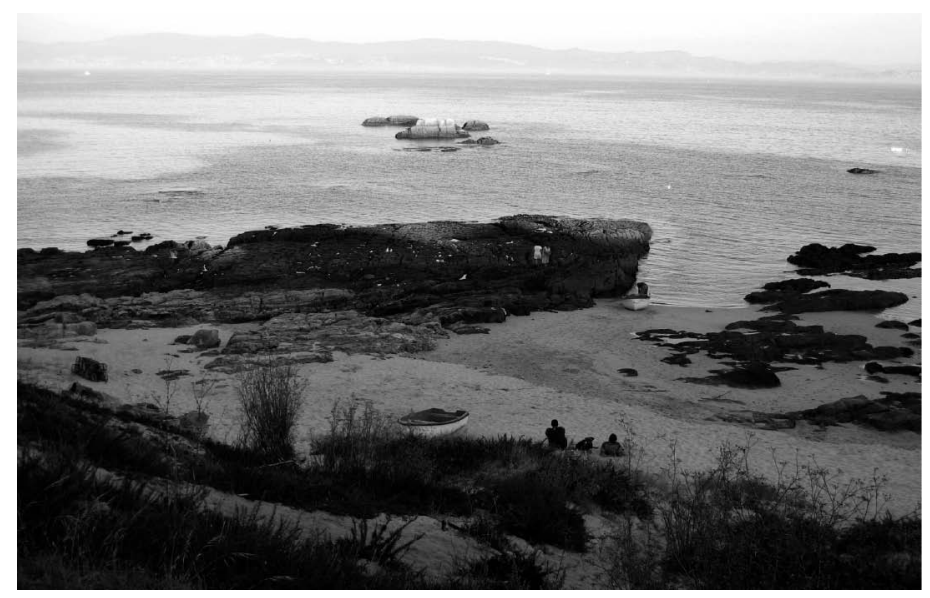

Figura 13. A esquina $\mathrm{N}$ da praia de Canexol funciona coma un embarcadoiro natural onde hoxe en día seguen a atracar as pequenas embarcacións dos mariñeiros da illa.

En canto á funcionalidade e cronoloxía das estruturas documentadas no areal de Canexol poucas precisións poden facerse con base nos datos actuais. Está claro que

\footnotetext{
${ }^{9}$ Neste sentido resulta interesante constrastar os datos coa tesis de C. Rodríguez Fernández ou a consulta de traballos recentes coma o de Aboal Fernández, R. e Castro Hierro, V. (Coord.). 2006. $O$ Castro de Montealegre. Noia, A Coruña: Editorial Toxosoutos. Ou o de Ayán Vila, X. M. 2005. Os Castros de Neixón. Noia, A Coruña: Editorial Toxosoutos.
} 
non se pode facer unha secuencia cronocultural con base nunha estratigrafía e poñela en relación co material cerámico localizado. O que si é certo que, polas evidencias identificadas, parece que estamos ante un conxunto de estruturas relacionadas cun asentamento costeiro que destinaría a súa produción ao consumo ben local, ben coa península. Pero, a zona visible do xacemento non permite determinar si esas estruturas amortizan estruturas castrexas previas ao asentamento romano, se puideron formar parte dunha villa ou un pequeno asentamento cun área doméstica que contaría con algúns estanques ou pías de salgadura entre outras construcións, ou ben se constitúen unha factoría illada e esa comunidade estaría asentada no castro... En relación con isto, pouco se sabe sobre a secuencia cronocultural e tipolóxica, tampouco sabemos nada sobre a súa extensión, e que ámbito puido ocupar xa que, pese a estar emprazadas nun rechán antes do descenso á praia, a erosión foi borrando de forma vertical o rexistro.

Encol do emprazamento axeitado para a construción de factorías de salgadura cómpre sinalar a edificación na illa, moi posterior, dunha fabrica de salgadura contigua ao peirao e á praia de Curro $^{10}$ agora desaparecida. Foi nos anos 1835-40 cando se instalou esta fábrica. A actividade dos insulares dirixíase á pesca para subministrar á fábrica. Neste momento constátase a chegada de xentes do Barbanza cun aumento da poboación debido a unha época de mellora económica. Pero parece ser que as irregularidades na pesca da sardiña ocasionaron o declive e o peche da empresa (Vilas et al. 2005: 146). S. Portela (1954: 68) a describe, xa na década dos cincuenta coma "unha construcción arruinada, de planta baixa con adintamentos de extensa galería e con vistas ao mar".

De todos os xeitos, hai que ter en conta que a existencia destas factorías documentadas na costa vinculadas á explotación dos recursos mariños, tanto de salgaduras como de salinas, ten unha serie de implicacións que vai máis alá da conservación do peixe. A existencia destes xacementos leva implícito outro tipo de actividades e de coñecementos relacionados coa pesca, o comercio e o seu consumo e o seu estudo que permitirá valorar a importancia desta produción no contexto de Galiza.

\section{CONCLUSIÓNS}

É certo que estamos ante unha pequena mostra do rexistro arqueolóxico que contén a illa e, en concreto, esta zona de Canexol e que quizais esteámonos a aventurar con hipóteses arqueolóxicas máis ou menos acertadas do que poden ser

${ }^{10}$ Denominada tamén praia das Dornas. 
os restos documentados e do que representan, pero non é menos certo que se non o facemos estamos obviando parte dun rexistro de por si esquecido.

De feito, practicamente non quedou rastro algún no imaxinario da xente da illa con respecto a este lugar. E dicimos case porque efectivamente hai unha lenda que une de forma imaxinaria e simbólica o castro co illote de $O$ Cairo $^{11}$, situado no medio do mar, enfronte de Canexol, que pola súa forma e tamaño destaca entre o resto (figura 15). Segundo Irene Patiño Otero, veciña de Ons:

"Eu escoitaba dos antiguos que había un túnel que ía dende o Buraco dos Mouros, que baixabas por unhas escaleiras que ali había e ías a dar O Cairo por debaixo do mar. Cando eramos pequenos e iamos co gando a pastar por alí, iamos ó buraco e baixabamos polas escaleiras pero, cando se facía escuro, escapabamos correndo para fora. Escoitabamos da xente que ali estivera que no buraco había moito ouro pero nos nunca o miramos...".

Quizais esas escasa referencias imaxinarias poden deberse a que eses restos foron invisibilizados fai moito tempo. De feito é significativo que nun mapa da illa

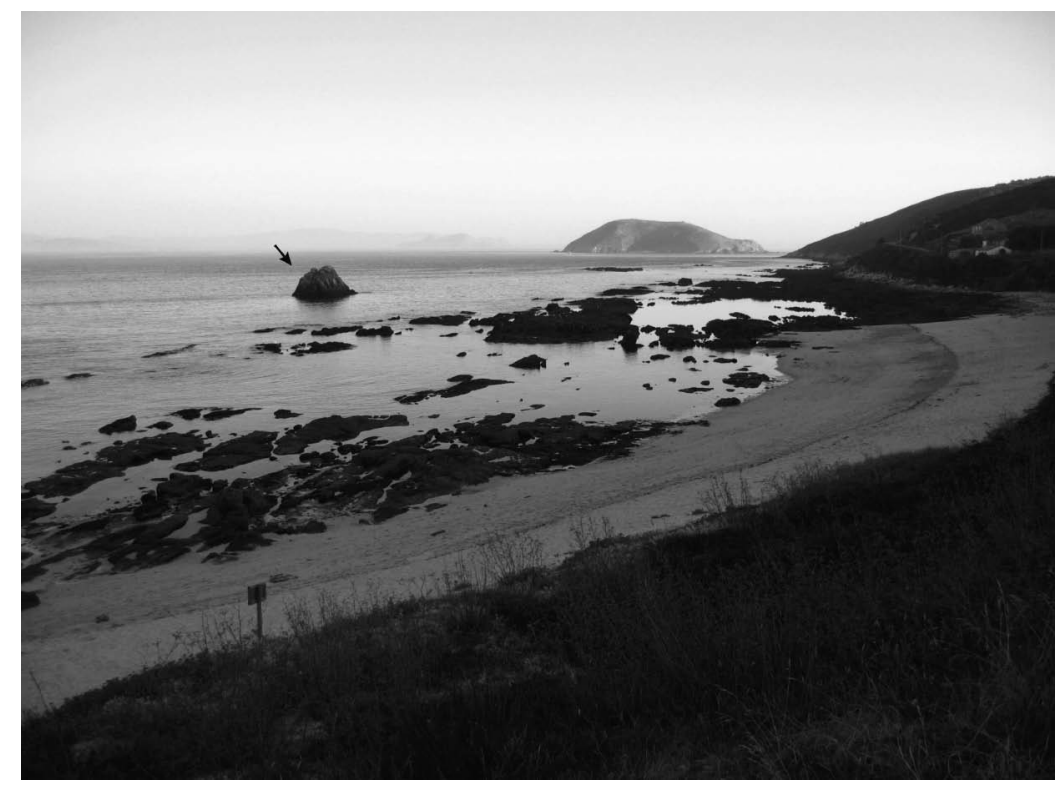

Figura 15. Vista cara ao S da praia de Canexol co illote do Cairo (indicado cunha flecha) e a illa de Onza ao fondo.

${ }^{11}$ Poderíase pensar que o seu nome de Cairo derivaría da súa forma de peñón cunha característica forma de dente canino, que en galego denominase cairo. 
de 1904, que aparece nunha publicación de S. Mörling et al. (2006), non apareza nada ao respecto e si parte das construcións domésticas que se conservan na actualidade. O amplo paquete de terra que aparece selando as estruturas de Canexol, descrito anteriormente, debeuse de depositar nun tempo no que estas estruturas eran ruínas dun pasado sen ningunha utilidade e polo tanto un estorbo. Posiblemente, coa necesidade de ganarlle terreo á illa explanáronse dándolle un uso a este terreo totalmente diferente. E, ao non se percibir nada en superficie, o tempo propiciou que se borraran tamén da memoria das xentes.

Xunto a estas dúbidas xurdidas pola escaseza do rexistro dispoñible pero de importancia cultural considerable hai que engadir o mal estado de conservación do propio xacemento por varias razóns:

- Pola súa situación, ao marxe do cantil do areal, facendo que sexa unha zona especialmente sensible á erosión. De feito, aprécianse derrubos actuais, xa que na area hai restos dos muros e de materiais asociados á actividade realizada nesa construción.

- A situación de emerxencia provocada polo desastre do Prestige fixo que, ademais de que nos perfís póidanse ver restos de chapapote, se construíse unha nova vía de acceso á propia praia, e que coincide coa zona onde as estruturas construtivas son máis senlleiras e abundantes. Consta dunhas escadas formadas por troncos fincados no perfil e apoiadas con material procedente da zona.

Neste sentido, considérase que se non se actúa dalgunha maneira perderase unha boa parte da historia e, en definitiva, parte da identidade dos seus habitantes.

Por outra banda, non debemos de esquecer que este é unha entidade máis dentro dun amplo rexistro cultural que con seguridade contén a illa. Esa paisaxe natural foise conformando ao longo do tempo nunha paisaxe cultural onde a propia natureza, o compoñente material resultado da acción das actividades humanas en diferentes épocas e o compoñente inmaterial ou intanxible, xa máis alá do obxecto rexistrado, foise formando un entramado de relacións sociais e culturais, e de coñecementos vinculados a esa materialidade, a partir da cal se constrúe a cultura dunha sociedade. Non hai paisaxes naturais, que todo o que vemos son paisaxes antrópicas modificadas, construídas, usadas e semantizadas polas xentes para establecerse, vivir nelas e delas o longo do tempo. Hai unha paisaxe castrexa, hai unha paisaxe romana, medieval, e unha paisaxe tradicional agrícola, gandeira e pesqueira. Como di Staffan Mörling (2006) "O par de vacas, o xugo de bois e a dorna eran as bases da economía do fogar da illa". Son os tres elementos que posiblemente estiveron presentes dunha ou doutra maneira ao longo do tempo. $\mathrm{O}$ que si parece certo e que a maior parte dese patrimonio está por descubrir. 


\section{AGRADECEMENTOS}

Ao mar, á illa... aos isleños, a Ángela e a Pedro... porque con eles descubrín outra illa.

\section{BIBLIOGRAFÍA}

ABOAL FERNÁNDEZ, R. e Castro Hierro, V. (Coord.). 2006. O Castro de Montealegre. Noia, A Coruña: Editorial Toxosoutos.

ALONSO ROMERO, F. 1981. Los orígenes del mito de la Santa Compaña de las islas de Ons y Sálvora. Cuadernos de Estudios Gallegos, Tomo XXXII, 285-306. Instituto Padre Sarmiento. Santiago de Compostela.

AYÁN VILA, X. M. 2005. Os Castros de Neixón. Noia, A Coruña: Editorial Toxosoutos.

BALLESTEROS ARIAS, P.; Criado Boado, F.; Andrade Cernadas, J. 2006 .Formas y fechas de un paisaje agrario de época medieval: A Cidade da Cultura en Santiago de Compostela. Arqueología Espacial, 26 Teruel.

BLANCO CHAO, R. e Costa Casais, M., 2001. Influencia de formas y depósitos antiguos en la dinámica litoral: un ejemplo de la costa sur de Pontevedra (Galicia). Actas del XVI Congreso de Geógrafos Españoles. Univ. de Oviedo, CeCodet; AGE, GEA, pp. 137-140.

BOUZA BREY, F.; Álvarez Blázquez, J. e Massó Bolivar, E. 1971. Las aras del santuario galaicoromano de Donón (Hío-Cangas). Cuadernos de Estudios Gallegos, Tomo XXVI, 64-81. Instituto Padre Sarmiento. Santiago de Compostela.

CAMPOS, J. M.; PÉREZ, J. A. E VIDAL, N. O. 1996 (e.p.a.). Las industrias de salazones del litoral onubense: el caso de El Eucaliptal (Punta Umbría Huelva). Actas Segundo Encontro de Arqueología do Sudoeste. Faro.

CAMPOS, J. M.; PÉREZ, J. A. e Vidal, N. O. 1999. Las cetariae del litotral onubense en época romana. Huelva. Servicio de Publicaciones de la Universidad de Huelva.

COSTA CASAIS, M. 1995. Formas e procesos costeiros nun sector da costa Occidental Galega (Fisterra-Corrubedo). Depósitos costeiros e evolución xeomorfolóxica. Memoria de Licenciatura. Facultade de Xeografía e Historia. Universidade de Santiago de Compostela.

DAS CASAS, A. 1934. A illa de Ons. Rev. Nós. T. II. Seminario de Estudos Galegos. Santiago.

GONZÁLEZ-ALEMPARTE FERNÁNDEZ, J. M. 2003. Crónicas históricas de las islas Cíes. (De mitos, ermitaños, piratas y mar por medio). Betanzos, A Coruña: Briga Edicións.

HIDALGO CUÑARRO, J. M. 1990-91. Últimas excavaciones arqueológicas de urgencia en Vigo: castros y yacimientos romanos. Castrelos, III-IV: 191-215. Vigo: Museo Municipal "Quiñones de León”.

LORENZO FERNÁNDEZ, X. 1962. Etnografía: cultura material. En R. Otero Pedrayo, Historia de Galiza. Tomo II. Buenos Aires: Editorial Nós.

LOURENZO FERNÁNDEZ, X. 1934. Notas do meu diario arqueolóxico. Revista Nós, tomo XI, ${ }^{\circ}$ 130. 
MÖRLING, S.; OTERO PATIÑO, J. E MÖRLING, M. 2006. A Illa de Ons, unha cultura, unha identidade. Xunta de Galicia. Consellería de Pesca e Asuntos Marítimos.

NAVEIRO LÓPEZ, J. M. 1991. El comercio antiguo en el NW peninsular. № 5 . Museo Arqueolóxico de A Coruña.

PORTELA PAZOS, S. 1954. Apuntes para la Historia de la Isla de Ons. Cuadernos de Estudios Gallegos, Tomo IX, 35- 73. Santiago de Compostela: Instituto Padre Sarmiento.

RODRÍGUEZ LÓPEZ, C. Aproximación ao estudo da explotación do mar na Galicia Romana. En: Galicia: da romanización a xermanizaxión. Problemas históricos e culturais en Homenaxe a Fermín Bouza Brey (1901-1973). Santiago de Compostela: Museo do Pobo Galego.

SUÁREZ PIÑEIRO, A. M Ma 2003. La explotación del mar en la Galicia romana: El ejemplo de las instalaciones de salazón. Cuadernos de Estudios Gallegos, $\mathrm{n}^{\circ}$ 116, tomo I. Santiago de Compostela: Instituto de Estudos Galegos Padre Sarmiento.

VÁZQUEZ VARELA, J. M. (Coord.) 1990. El hombre y el mar en la costa suroeste de Pontevedra. Vigo: Exma. Diputación de Pontevedra. Servicio de Publicaciones.

VÁZQUEZ VARELA, J. M.; REY SALGADO, J. E CAMINO, M. 1992. La pesca en el mundo castreño y romano de Galicia. En: Galicia: da romanización a xermanizaxión. Problemas históricos e culturais en Homenaxe a Fermín Bouza Brey (1901-1973). Santiago de Compostela: Museo do Pobo Galego.

VILAS, A.; GAMALLO, M.; FRAMIL, J.; BOMACHE, J.; SANZ, K.; LOIS, M. E TOUBES, M. 2005. Guía de visita do Parque Nacional Marítimo-Terestre das Illas Atlánticas de Galicia. O. A. Parques Nacionales. 